\title{
Efficiency, Profitability and Stability of Nepalese Commercial Banks
}

\author{
Pitri Raj Adhikari \\ Lecturer, Tribhuvan University \\ Email: mailtoadhikarisir@gmail.com
}

\begin{abstract}
Efficiency, profitability and stability become an area of emergent concern in the literature and the practice. This paper attempts to examine the efficiency, profitability and stability of the Nepalese commercial banks and shows the importance of banking activities rather than simply profit achieved. Descriptive and causal-comparative research designs are used and data are collected from the financial reports of respective banks and NRB reports during the period of 2011/12 to 2019/20 of 27 commercial banks with 243 observations. Descriptive statistics have been used to present quantitative data in a manageable form and the relationship between dependent and independent variables are examined using correlation, simple and multiple regression analysis. It is found a negative and significant relationship between bank efficiency and profitability; $a$ positive and significant relationship between bank efficiency and stability. Perhaps, this paper may be the first attempt to examine the determinants of efficiency, profitability and stability of Nepalese commercial banks. It is expected this study will bring new insight into the banking field and would provide a framework and guidelines for future study in Nepalese financial sectors.
\end{abstract}

Keywords: efficiency, profitability, stability, z-score, bank size

\section{Background}

The efficiency and performance of the banking industry is a researchable issue for professionals, regulators, and academicians for the last few decades in developing economies. Studying efficiency in banking can be used for shareholders, policymakers, managers, market analysts, investors, clients and government regulators (Andries \& Capraru, 2014).The overall performance of the banking industry in a developing economy is affected by efficiency, profitability, and stability. To increase the economic growth and development of a nation, the banking sector plays a vital role (Kenourgios \& Samitas, 2007). Financial institutions are interested to maximize profit for which banks collect deposits at a lower rate and invest at a higher rate (Rivai et al., 2007). Similarly, banks increase their profitability by investing more in financial innovations and branch networks and expand their market shares to boost their operational efficiency (Lotto, 2019). According to Alharthi (2016), the interrelationship between efficiency, profitability and stability is of great importance for the banking sector. Miah et al. (2020) 
observed that stability is positively related to profit efficiency, whereas, Alber (2017) revealed that banking efficiency is negatively correlated to financial stability.

Efficiency is the ability to achieve a higher amount of output by using a lower amount of input. Efficient banks can use minimum inputs to generate maximum outputs, which could raise the sustainability of commercial banks. According to Cvilikas and Dumbliauskiene (2016), efficiency is the maximum potential ratio between the input and output of the product development process that shows the optimal distribution of available resources that would allow achieving the maximum potential. Similarly, according to Bergre et al. (1993), efficiency for financial institutions indicates improved profitability, the greater amount of funds channeled in, better price and service quality for consumers, and greater safety in terms of improved capital buffer in absorbing risk. Thalassinos et al. (2015) stated that the topicality of bank efficiency, profitability, and stability analysis became especially topical after the global financial crisis. Alharthi (2016) analyzed the efficiency, profitability and stability in the banking sector jointly and observed that positive determinants allow managers to make more decisions based on positive factors. However, through raising efficiency, profitability and stability in banking, managers can aim to avoid negative variables altogether. Based on determinants of efficiency, profitability and stability, policymakers can take appropriate strategic decisions to achieve the target goals. Competition in the banking industry has increased because of deregulation, liberalization, and globalization, hence, the banking sector has the challenge to get a higher level of efficiency, profitability, and stability.

Athanasoglou et al. (2008) stated that an efficient, profitable and stable banking system safeguards economic conditions from negative shocks. Besides, macroeconomic and bank-specific factors are found to affect bank stability more consistently as compared to market-specific factors (Shijaku, 2016). Similarly, Yildirim (2010) revealed that efficient banks are more profitable, and pure technical efficiency and scale inefficiency are positively related to size. Hence, the trend in the performance levels over the period suggests that macroeconomic conditions had a profound influence on the efficiency measures. Likewise, the most profitable banks are more efficient, competitive and stable (Apergis, 2014). Likewise, Gajurel (2010) observed that state-owned Nepalese banks are less cost-efficient than other banks (domestic and foreign). Banks having higher financial capital, larger loan ratio and higher profit tend to be more cost-efficient, however, banks with higher credit risk tend to be less cost-efficient. Further, size has a consistently inverse impact on cost efficiency. Similarly, Panta and Bedari (2019) found that level of cost efficiency of the Nepalese commercial banks has increased substantially over the period with small size banks exhibiting higher cost efficiency as compared to medium size. Pradhan and Gajurel (2011) examined the structure performance hypotheses in the 
Nepalese context and revealed that bank size and GDP growth rate have a positive influence on banks' profitability.

Sulaeman et al. (2019) revealed that the loan to deposit ratio, financing to deposit ratio, the net interest margin to net operating margin, the capital adequacy ratio (CAR), and economic growth have a significantly positive effect on the efficiency of banks. Further, they examined that loan to deposit ratio, the CAR, economic growth, and inflation have a significantly positive effect on the efficiency of conventional banks. However, the NIM has a significantly negative effect. Similarly, Rahman et al. (2015) found that capital strength and loan intensity have a positive significant impact on profitability, however, cost efficiency and off-balance sheet activities have a significant and negative impact on profitability. Similarly, non-interest income, credit risk and GDP growth have observed as significant determinants for NIM. Further, size has a positive impact on ROA whereas inflation has negatively and significantly related to ROA and ROE. Sufian (2016) found a positive relationship between efficiency and bank size, capitalization and foreign ownership. The study of efficiency, profitability and stability becomes a crucial issue in the discipline. However, there is the absence of joint studies that examined the relationship between efficiency, profitability and stability of the Nepalese commercial banks. Hence, the study is essential to examine the efficiency, profitability and stability of Nepalese commercial banks. As a result, the study is expected to contribute to the existing literature by providing new knowledge and information.

\section{Objectives}

This study has the following objectives:

- To analyze the relationship between bank-specific variables and efficiency, profitability and stability of Nepalese commercial banks.

- To assess the relationship between macroeconomic variables and efficiency, profitability and stability of Nepalese commercial banks.

- To examine the impact of macroeconomic variables on efficiency, profitability and stability of Nepalese commercial banks.

\section{Research Hypothesis}

The study has set the following alternative hypotheses:

$\mathrm{H}_{1}$ : There is a positive relationship between bank size with bank efficiency and profitability.

$\mathrm{H}_{2}$ : There is a negative relationship between bank size with bank stability.

$\mathrm{H}_{3}$ : There is a negative relationship between capital adequacy ratios with bank efficiency. 
$\mathrm{H}_{4}$ : There is a positive relationship of capital adequacy ratios with bank profitability and stability.

$\mathrm{H}_{5}$ : There is a negative relationship of non-performing loan ratios with bank efficiency, profitability and stability.

$\mathrm{H}_{6}$ : There is a negative relationship of Z-score with bank efficiency, profitability and stability.

$\mathrm{H}_{7}$ : There is a positive relationship of cost to income ratios with bank efficiency.

$\mathrm{H}_{8}$ : There is a negative relationship of cost to income ratio with bank profitability and stability.

$\mathrm{H}_{9}$ : There is a positive relationship of return on assets with bank efficiency, profitability and stability.

$\mathrm{H}_{10}$ : There is a positive relationship of gross domestic product with bank efficiency, profitability and stability.

$\mathrm{H}_{11}$ : There is a negative relationship of inflation with bank efficiency, profitability and stability.

\section{Literature Review}

Financial institutions, basically the banking industry, have a vital role to develop the economy of a nation. Empirical studies concluded that several variables are important in determining the relationship between efficiency, profitability and stability of commercial banks. The interrelationship between efficiency, profitability and stability has great importance for the banking sector (Alharthi, 2016).

Mathuva (2009) assessed a positive and significant relationship between capital adequacy and bank profitability, and a negative and significant relationship between cost to income ratio and bank efficiency and profitability. AbdKarim et al. (2010) stated that there is no significant difference in cost efficiency between banks in Singapore and Malaysia although banks in Singapore exhibit a higher average cost efficiency score. Further, higher non-performing loans reduced cost efficiency and lower cost efficiency increases non-performing loans. Pradhan and Gajurel (2011) examined that the traditional structure-conduct-performance hypothesis and quiet life hypothesis were better explained concentration-profitability relation in the Nepalese banking industry. Similarly, there has weak support for efficiency structure hypotheses. In addition, this study also found that bank size and GDP growth rate have a positive influence on banks' profitability. Thagunna and Poudel (2013) observed that there is no significant relationship between ownership structure and efficiency level of banks. Further, it is also found that there were no notable differences in the efficiency levels of banks according to the size of their assets. 
Safavi (2014) revealed that the factors affecting financial stability in the case of stateowned and private banks were not identical. It was found that there is a diverse impact on the banking industry of national currency and GDP as the latter leads to financial stability and reduction in the case of former brings financial stability. The author also observed an inverse relationship between the Z-score and the stability of banks. Stancic et al. (2014) observed that there is a significant but negative relationship between bank profitability and board size. Similarly, the proportion of independent directors and bank profitability were negative and insignificant. A negative but weak impact of ownership concentration on bank profitability was found. Besides, privately-held domestic banks outperform state-owned and foreign banks. Murerwa (2015) found a negative relationship between financial performance and the management of bank expenses. The author also found that there has a positive and significant relationship between bank profitability and the efficiency of banks. A study conducted by Tan and Anchor (2016) revealed that greater profitability of a bank leads to a higher bank fragility and greater insolvency risk seeker bank stability leads to greater profitability of a bank. Zheng et al. (2017) revealed that size, capital, ownership structure and market share of the bank have a significant impact on bank efficiency but credit risk has an insignificant impact on bank profit efficiency. Vinh (2017) investigated that the non-performing loan has a statistically significant negative effect on banks profitability and lending behavior. Khaddafi et al. (2017) found a positive relationship between Z-score and bank efficiency and profitability. The chances of bankruptcy would be even greater if the management company did not immediately take action evaluation of the company's financial condition. Khalil and Khalil (2017) investigated that bank size significantly and positively influenced the bank profitability while the asset management inversely affected the bank profitability.

Odundo and Orwaru (2018) concluded that bank size has a significant negative effect on bank stability. It was also confirmed that bank capital has a significant positive effect on stability. Therefore, to guarantee banks' soundness, appropriate policies should be taken in place to encourage them to achieve greater capital bases. Hafez (2018) revealed a significant positive relationship between the efficiency of banks and capital adequacy ratios, credit risk, profitability, bank size and the quality of management. It also observed that the efficiency of banks determines the level of capital and risk borne by banks. Similarly, a study conducted by Akhter (2018) stated that capital-efficiency-risk relationship as banks' operational efficiency and risk has a direct relationship with the size of bank and capital which indicates that a bank's efficiency (operational) is improved at decorating rate because of increase in bank's risk with the increased size of bank and capital. Likewise, Datta and Al Mahmud (2019) observed a positive 
relationship of bank's profitability with explanatory variables such as operating efficiency, capital adequacy and structure of loans. They also found that the capital held by banks has higher than the provision of minimum capital requirement guided under Basel II accord. Belas et al. (2019) observed that cost efficiency was mainly explained by the capitalization, profitability, loan risk, and market structure, conditions of the economy and development of inflation. Lotto (2019) examined that bank liquidity and capital adequacy have a positive relationship with bank operating efficiency. Similarly, bank profitability and operating efficiency are positively correlated that indicates banks should emphasize improving their earning generating power to increase their operational efficiency. Ali \& Puah (2019) found that credit risk, stability, bank size and funding risk statistically significant impact on profitability but liquidity risk had a statistically insignificant impact on profitability. Similarly, credit risk had an insignificant impact on stability, however, funding risk, bank size, profitability and liquidity risk had a statistically significant effect on stability.

Ozili (2019) found that regulatory capital ratios, banking concentration, banking efficiency, the size of non-performing loans and higher financial depth are significant determinants of banking stability. Lardic and Terraza (2019) revealed a significant and positive profitability persistence for medium-sized banks but not found real evidence of a positive relationship between profitability and efficiency of the bank. Further, they observed that profitability and liquidity risk depend on bank size while capitalization level increases. Jahan (2020) found a positive relationship among capital adequacy, solvency, credit risk and stability. The provision of BASEL of CAR has played a major role to deduct the dominance of large banks that ensures the growth of the bank. Abiodun et al. (2020) examined that the capital adequacy ratio had a significant strong positive relationship with the profitability of the bank. They also found that capital adequacy ratio has among the main predictors of mid-tier commercial banks' financial performance. Alshebmi et al. (2020) indicated a negative insignificant weak relationship between nonperforming loans ratio (NPLs) and return on assets ratio (ROA), growth gross domestic product (GGDP), bank liquidity risk (BLQ), and credit risk. Besides, it was also observed a positive insignificant relationship between capital adequacy ratio and non-performing loan ratio. Khan et al. (2020) found that the profitability and operating efficiency of banks are negatively correlated with nonperforming loans but are statistically significant. Further, they revealed that income diversification and capital adequacy have a negative association with nonperforming loans but are statistically insignificant. Onyango and Olando (2020) revealed that there is a positive and significant impact of interest rate spread on non-performing loans (NPL). Further, 
operating efficiency has directly proportional to NPLs and it has a moderate positive and significant impact on NPLs.

\section{Conceptual Framework}

The following conceptual framework has been designed to exhibit the main focus and scope of this paper in terms of variables included.

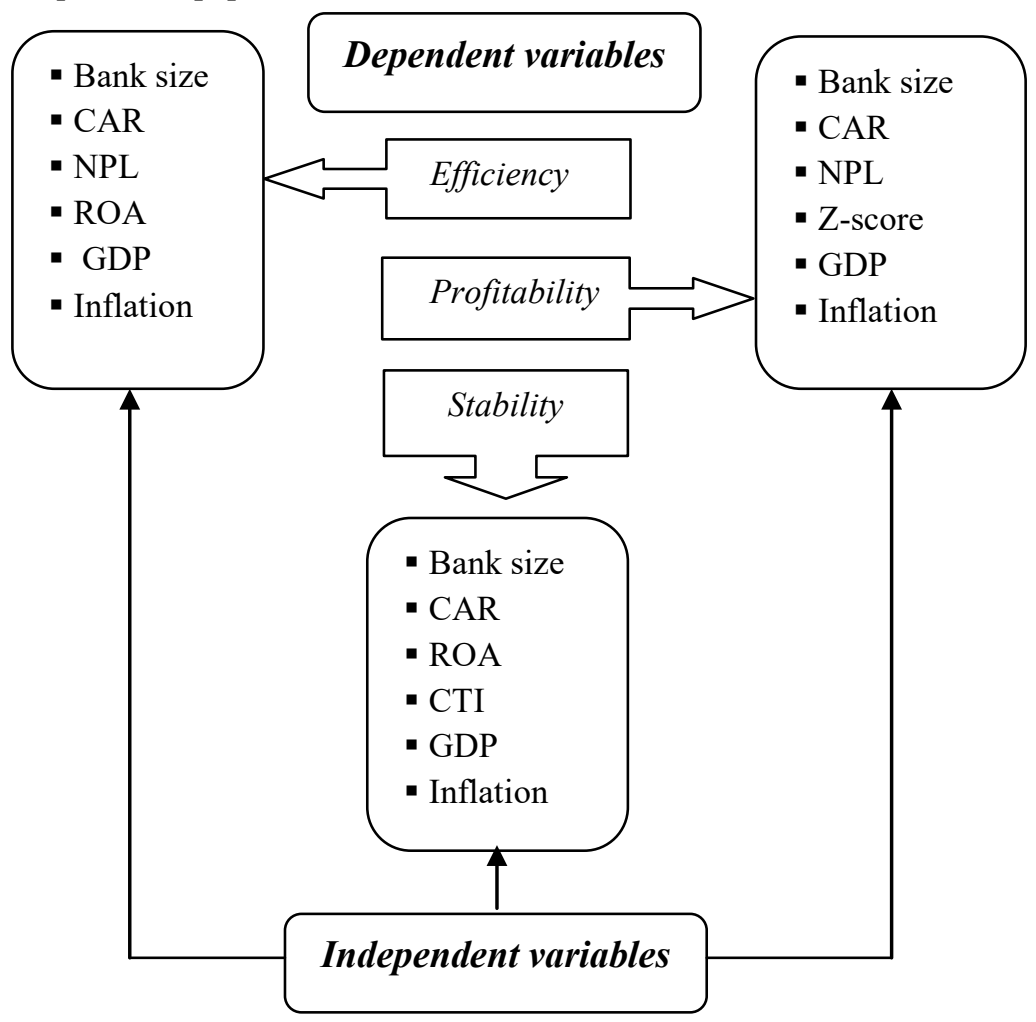

Figure 1. Conceptual framework

\section{Research Methods}

This paper used a descriptive research design for fact-finding and searching for adequate information about the variables. Similarly, causal-comparative research design has employed to examine the directions, patterns, magnitude and forms of the observed relationship between efficiency, profitability and stability of the Nepalese commercial banks. 
Data are collected from the Banking and Financial Statistics and bank supervision report published by Nepal Rastra Bank and annual reports of the respective banks during the period of 2011/12 to 2019/20 of 27 commercial banks having total observation of 243.Descriptive statistics have been used to present quantitative data in a manageable form andthe relationship between dependent and independent variables are examined using correlation, simple and multiple regression analysis.

The following equation models areused to test the hypothesis:

$\mathrm{EFF}_{\mathrm{it}}=\beta_{0}+\beta_{1} \mathrm{BS}_{\mathrm{it}}+\beta_{2} \mathrm{CAR}_{\mathrm{it}}+\beta_{3} \mathrm{ROA}_{\mathrm{it}}+\beta_{4} \mathrm{NPL}_{\mathrm{it}}+\beta_{5} \mathrm{GDP}_{\mathrm{it}}+\beta_{6} \mathrm{INF}_{\mathrm{it}}+\mathrm{eit}$

$\mathrm{PRO}_{\text {it }}=\beta_{0}+\beta_{1} \mathrm{BS}_{\mathrm{it}}+\beta_{2} \mathrm{CAR}_{\mathrm{it}}+\beta_{3} \mathrm{Z}_{\text {-score }}+\beta_{4} \mathrm{NPL}_{\mathrm{it}}+\beta_{5} \mathrm{GDP}_{\text {it }}+\beta_{6} \mathrm{INF}_{\text {it }}+$ eit

$\mathrm{STA}_{\mathrm{it}}=\beta_{0}+\beta_{1} \mathrm{BS}_{\mathrm{it}}+\beta_{2} \mathrm{CAR}_{\mathrm{it}}+\beta_{3} \mathrm{ROA}_{\mathrm{it}}+\beta_{4} \mathrm{CTI}_{\mathrm{it}}+\beta_{5} \mathrm{GDP}_{\mathrm{it}}+\beta_{6} \mathrm{INF}_{\mathrm{it}}+\mathrm{eit}$

Where, $E F F=$ Bank efficiency, defined as the cost to income ratio in per cent; $P R O=$ Bank profitability, defined as net income to total assets in per cent; STA=Bank stability, defined as a logarithm of Z-score in per cent; BS = Bank size, defined as the natural logarithm of total assets of the bank in billions of rupees; CAR = Capital adequacy ratio, defined as the ratio of equity to total assets in per cent; $R O A=$ Return on assets, defined as net income to total assets in per cent; Z-score = Z-score, defined as a logarithm of Zscore in per cent; $N P L=$ Non-performing loan, defined as non-performing loan to total loan in per cent; $C I I=\frac{O H}{N I+N C+O I}, O H$ (overhead) is all staff costs and other general operating expenses including depreciation costs, NI (net income) and NC (commission) derived from banking intermediation activities are taken into account and OI (other net income) from activities unrelated to banking intermediation; GDP = Gross domestic product, defined as the natural logarithm of gross domestic product in millions of rupees; INF = Inflation rate, defined as a consumer price index in per cent; $e_{i t}=$ Error term; $\beta_{0}=$ Constant term; $\beta_{1}, \beta_{2}, \beta_{3}, \beta_{4}, \beta_{5}$ and $\beta_{6}=$ Beta coefficients of variables.

\section{Limitations}

Market capitalization, ownership structure, return on equity, credit risk, financial leverage, and economic growth etc. are not considered in this paper, however, these variables affect the efficiency, profitability, and stability of banks. Similarly, to measure efficiency, the cost to income ratio has been used rather than the DEA score. Further, return on assets has used to represent the profitability of the banks, however, other indicators like return on equity, earning per share, Tobin's Q ratio, net interest income have ignored. 


\section{Results and Discussion}

\section{Structure and pattern of bank-specific variables}

Table 1 presents the structure and pattern of efficiency, profitability and stability of the Nepalese commercial banks for the period of 2011/12 to 2019/20.

Table 1

Structure and Pattern of Bank-specific Variables

\begin{tabular}{lllllll}
\hline Year & \multicolumn{2}{c}{ Efficiency } & \multicolumn{2}{c}{ Profitability } & \multicolumn{2}{c}{ Stability } \\
\cline { 2 - 7 } & Mean & S.D & Mean & S.D & Mean & S.D \\
\hline $2011 / 12$ & 47.3 & 16.52 & 1.35 & 1.02 & 15.81 & 14.15 \\
$2012 / 13$ & 44.57 & 17.43 & 1.37 & 1.31 & 13.44 & 6.31 \\
$2013 / 14$ & 43.42 & 18.31 & 1.44 & 1.02 & 13.42 & 4.11 \\
$2014 / 15$ & 42.27 & 14.15 & 1.51 & 0.69 & 13.43 & 3.69 \\
$2015 / 16$ & 39.42 & 11.52 & 1.72 & 0.63 & 16.38 & 12.15 \\
$2016 / 17$ & 40.64 & 12.26 & 1.75 & 0.59 & 18.42 & 4.42 \\
$2017 / 18$ & 46.52 & 13.89 & 1.75 & 0.62 & 18.85 & 4.55 \\
$2018 / 19$ & 42.91 & 9.73 & 1.75 & 0.51 & 18.22 & 3.91 \\
$2019 / 20$ & 40.38 & 9.27 & 1.75 & 0.45 & 18.05 & 3.85 \\
\hline
\end{tabular}

Source: Annual reports of banks

Table 1 shows that the average efficiency ratio varies widely over time. It is observed that the average efficiency ratio in $2011 / 12$ was 47.30 per cent and decreases to 39.42 in $2015 / 16$. The bank efficiency was maximum in the year 2011/12 and minimum in 2015/16.Similarly, the average profitability ratio (net income to total assets) computed across the years has an upward and constant trend over time. It is found that the average profitability ratio in the financial year $2011 / 12$ is $1.35 \%$, has found to increase to $1.75 \%$ in 2016/17 and constant thereafter till 2019/20. Further, the results exhibit the fluctuating trend of stability ratio (Z-score) computed across the different financial years from 2011/12 to 2019/20. Z-score shows little up and downs over the study period for the Nepalese commercial banks. Firstly, Z-score is decreasing from 2011/12 to 2014/15 and found to be increasing from $2014 / 15$ to $2017 / 18$ and start to decline thereafter till the fiscal year 2019/20.Thus, the maximum value of bank stability can be observed in the year 2017/18 and the minimum can be observed in 2013/14. This indicates that the Nepalese commercial banks are more stable over time. 


\section{Structure and pattern of bank size, capital adequacy ratio and non-performing loan}

Table 2 presents the structure and pattern of bank size, capital adequacy ratio, and nonperforming loan of the Nepalese commercial banks for the period of 2011/12 to 2019/20.

Table 2

Structure and Pattern of Bank Size, Capital Adequacy Ratio, and Non-performing Loan

\begin{tabular}{|c|c|c|c|c|c|c|}
\hline \multirow[t]{2}{*}{ Year } & \multicolumn{2}{|c|}{ Bank size } & \multicolumn{2}{|c|}{$\begin{array}{c}\text { Capital } \\
\text { adequacy ratio }\end{array}$} & \multicolumn{2}{|c|}{$\begin{array}{c}\text { Non-performing } \\
\text { loan }\end{array}$} \\
\hline & Mean & S.D & Mean & S.D & Mean & S.D \\
\hline $2011 / 12$ & 35.29 & 23.04 & 12.38 & 9.53 & 2.25 & 2.17 \\
\hline 2012/13 & 42.18 & 24.25 & 12.09 & 9.45 & 2.5 & 2.53 \\
\hline 2013/14 & 49.11 & 26.55 & 11.62 & 2.5 & 2.92 & 4.58 \\
\hline $2014 / 15$ & 60.03 & 30.33 & 12.19 & 1.91 & 2.17 & 1.69 \\
\hline 2015/16 & 75.77 & 33.64 & 12.44 & 1.66 & 1.72 & 1.86 \\
\hline 2016/17 & 91.47 & 34.86 & 14.32 & 2.61 & 1.67 & 1.74 \\
\hline $2017 / 18$ & 107.42 & 37.79 & 14.43 & 3.05 & 1.48 & 1.27 \\
\hline 2018/19 & 128.07 & 44.72 & 14.09 & 2.29 & 1.35 & 1.18 \\
\hline $2019 / 20$ & 135.46 & 46.82 & 14.02 & 2.18 & 1.33 & 1.17 \\
\hline
\end{tabular}

Source: Annual reports of banks

Table 2 exhibits the size of the bank in terms of total assets (Rs in billion) which has been computed for the Nepalese commercial banks from the year 2011/12 to 2019/20. The results reveal that the bank size varies widely over time. It is observed that the average bank size in the financial year 2011/12 is Rs. 35.29 billion and has found to continuously increase to Rs. 135.46 billion in 2019/20. The minimum value of bank assets made by banks can be observed in the year 2011/12 and the maximum can be observed in 2019/20. Similarly, the capital adequacy ratio (in percentage) has been computed for the banks from the year 2011/12 to 2019/20.The table reveals the fluctuating trend of capital adequacy ratio computed across the different financial years from 2011/12 to 2019/20. The capital adequacy ratio shows little up and downs over the study period for the banks. First, the capital adequacy ratio is decreasing from 2011/12 to 2013/14, and found to be increasing trend from 2013/14 to 2017/18, and found to be decreasing trend from $2017 / 18$ to $2019 / 20$. Thus, the maximum value of capital adequacy ratio can be observed in the year 2017/18 (14.43\%) and the minimum can be observed in 2013/14(11.62\%). Further, the result states the fluctuating trend of nonperforming loans computed across the different financial years from 2011/12 to 2019/20. Non-performing loans show little up and downs over the study period for the banks. 
First, non-performing loans are increasing from 2011/12 to 2013/14 and found to be decreasing speedy trend from 2013/14 to 2019/20.Thus, the maximum value of nonperforming loans made by banks can be observed in the year 2013/14 (2.92\%) and the minimum can be observed in 2019/20 (1.33\%).

\section{Structure and pattern of real GDP and inflation}

The gross domestic product and inflation of Nepal are presented in Table 3.

Table 3

Structure and Pattern of Real Gross Domestic Product and Inflation of Nepal

\begin{tabular}{llll}
\hline Year & $\begin{array}{l}\text { Nominal GDP } \\
\text { (Rs. in Million) }\end{array}$ & $\begin{array}{l}\text { Percentage } \\
\text { Change }\end{array}$ & Inflation \% \\
\hline $2011 / 12$ & 1527344 & 11.73 & 8.3 \\
$2012 / 13$ & 1695011 & 10.98 & 9.9 \\
$2013 / 14$ & 1964540 & 15.9 & 9.1 \\
$2014 / 15$ & 2130150 & 8.43 & 7.2 \\
$2015 / 16$ & 2253163 & 5.77 & 9.9 \\
$2016 / 17$ & 2674493 & 18.7 & 4.5 \\
$2017 / 18$ & 3031034 & 13.33 & 4.2 \\
$2018 / 19$ & 3464319 & 14.29 & 4.6 \\
\hline Mean & 2342506.75 & 12.39 & 7.21 \\
S.D & 667877.77 & 4.11 & 2.46 \\
\hline
\end{tabular}

Source: NRB economic review 2019/20

The results show that the average gross domestic product is in an upward trend increasing from the form year 2011/12 to 2018/19. It is highest in the year 2018/19 (Rs. 3464319 million) and the lowest in 2011/12 (Rs. 1,527,344 million). It is observed that the average gross domestic product during the period $2011 / 12$ to $2018 / 19$ is Rs. 2342506.75 million and a standard deviation of Rs. 667877.77 million. Similarly, the table shows that the rate of annual inflation change fluctuates over 2011/12 to 2018/19. The average rate of inflation during the period $2011 / 12$ to $2018 / 19$ is 7.21 percent and a standard deviation of 2.46 percent. The highest rate of inflation was in the year 2012/13 and 2015/16 with 9.90 percent and the lowest was in the year 2017/18 with 4.20 percent. 


\section{Correlation analysis}

Table 4

Correlation Matrix

\begin{tabular}{lllllllll}
\hline Variables & EFF & PRO & STA & BS & NPL & CAR & GDP & INF \\
\hline EFF & 1 & & & & & & & \\
PRO & $-0.222^{* *}$ & 1 & & & & & \\
STA & $-0.232^{* *}$ & $0.304^{* *}$ & 1 & & & & \\
BS & 0.089 & $0.209^{* *}$ & 0.143 & 1 & & & \\
NPL & $0.463^{* *}$ & $-0.330^{* *}$ & $-0.274^{* *}$ & -0.074 & 1 & & \\
CAR & $-0.253^{* *}$ & 0.126 & $0.563^{* *}$ & $-0.173^{*}$ & $-0.361^{* *}$ & 1 & & \\
GDP & -0.068 & 0.107 & $0.346^{* *}$ & $0.727^{* *}$ & $-0.206^{* *}$ & $0.220^{* *}$ & 1 & \\
INF & -0.043 & -0.61 & $-0.318^{* *}$ & $-0.567^{* *}$ & $0.182^{*}$ & $-0.823^{* *}$ & $-0.242^{* *}$ & 1 \\
\hline
\end{tabular}

Note: The asterisk signs ( $\left(^{*}\right)$ and ( $\left.{ }^{*}\right)$ indicate that the results are significant at one percent and five percent levels respectively.

It is found a negative and significant relationship between the efficiency ratio and profitability ratio (Table 4) indicates a decrease in efficiency leads to an increase in profitability of banks. Similarly, the stability ratio is also negative and significantly correlated to the bank efficiency ratio which states that an increase in stability ratio leads to a decrease in inefficiency. However, the study reveals that bank size and nonperforming loans are positively related to bank efficiency ratio that exhibits that larger the bank size and non-performing loan higher would be the bank efficiency. Similarly, capital adequacy ratio and gross domestic product have a negative relationship with bank efficiency ratio which means higher the capital adequacy ratio and gross domestic product lower would be the bank efficiency. Further, inflation is also negatively correlated to bank efficiency ratio that indicates a decrease in inflation of country leads to increase in bank efficiency.

The results show that bank stability and bank size have a positive and significant relationship with profitability ratio that shows an increase in stability and size of bank leads to a rise in profitability. In contrast, the non-performing loans and inflation are negatively correlated to bank profitability ratios that reveal lower the non-performing loans and inflation rate higher would be the bank profitability. Further, capital adequacy ratio and GDP are positively correlated to the bank profitability ratio which indicates that higher the capital adequacy ratio and GDP higher would be the bank profitability. The results also show that bank size, CAR and GDP are positively correlated with bank stability ratio that indicates larger the bank size, CAR and GDP higher would be the stability of banks. On the other hand, there is the negative relationship of stability ratio 
between non-performing loans and inflation which reveals that greater the nonperforming loans and inflation lower would be the Z-score of banks.

\section{Regression analysis}

This section deals with regression results from various specifications of the models mentioned in the methodology. To test the validity of the model through the statistical test of significance such as t-test, F-test and adjusted coefficient of determination (Adj. $\mathrm{R}^{2}$ ) are also calculated.

Table 5

Regression Results using Bank Efficiency as the Criterion

\begin{tabular}{|c|c|c|c|c|c|c|c|c|}
\hline \multirow[t]{2}{*}{ Model } & \multirow[t]{2}{*}{ Constant } & \multicolumn{6}{|c|}{ Regression coefficients of } & \multirow{2}{*}{$\begin{array}{l}\text { Adj. } \\
\text { R_bar }\end{array}$} \\
\hline & & BS & CAR & ROA & NPL & GDP & INF & \\
\hline \multirow[t]{2}{*}{1} & 26.123 & 1.611 & & & & & & 0.002 \\
\hline & $(1.768)$ & -1.103 & & & & & & \\
\hline \multirow[t]{2}{*}{2} & 53.273 & & -0.843 & & & & & 0.063 \\
\hline & $(18.215)^{* *}$ & & $(3.714)^{* *}$ & & & & & \\
\hline \multirow[t]{2}{*}{3} & 47.987 & & & -2.971 & & & & 0.051 \\
\hline & $(26.973)^{* *}$ & & & $(3.231)^{* *}$ & & & & \\
\hline \multirow[t]{4}{*}{4} & 37.902 & & & & 2.819 & & & 0.208 \\
\hline & $(33.635)^{* *}$ & & & & $(7.673)^{* *}$ & & & \\
\hline & 42.315 & & -0.431 & & 2.545 & & & 0.212 \\
\hline & $(13.281)^{* *}$ & & -1.546 & & $(6.543)^{* *}$ & & & \\
\hline \multirow[t]{2}{*}{8} & 141.516 & & & & 2.781 & -7.521 & -1.437 & 0.219 \\
\hline & (1.997)* & & & & $(7.402)^{* *}$ & -1.514 & $(2.254)^{*}$ & \\
\hline \multirow[t]{2}{*}{9} & 50.674 & & -0.427 & -1.024 & 2.523 & & -0.804 & 0.225 \\
\hline & $(10.735)^{* *}$ & & -1.889 & -1.235 & $(5.996)^{* *}$ & & $(2.187)^{*}$ & \\
\hline \multirow[t]{2}{*}{10} & 192.634 & 4.371 & & -1.535 & 2.561 & -15.398 & -1.463 & 0.234 \\
\hline & $(2.618)^{*}$ & $(2.432)^{*}$ & & -1.71 & $(6.432)^{* *}$ & $(2.464)^{*}$ & $(2.303)^{*}$ & \\
\hline \multirow[t]{2}{*}{11} & 184.841 & 3.516 & -0.286 & -1.397 & 2.541 & -13.761 & -1.518 & 0.234 \\
\hline & $(2.612)^{*}$ & -1.761 & -0.998 & -1.576 & $(5.971)^{* *}$ & $(2.172)^{*}$ & $(2.376)^{*}$ & \\
\hline
\end{tabular}

Notes:

i. $\quad$ Figures in parenthesis are t-values.

ii. The asterisk signs (**) and (*) indicate that the results are significant at one percent and five percent levels respectively.

iii. Efficiency is the dependent variable.

Table 5 reveals that positive beta for bank size with efficiency indicates that the bank size has a positive impact on bank efficiency and this finding is similar to the findings of Ozili (2019) and Hernandez et al. (2019). However, the negative and significant beta for 
capital adequacy ratio with bank efficiency reveals that the capital adequacy ratio hurts bank efficiency and this result is consistent with the findings of $\mathrm{Vu}$ and Nahm (2013) and Zhang et al. (2012). Similarly, the beta coefficients for return on assets are negative and significant with bank efficiency that concludes the return on assets hurts bank efficiency and this finding is similar to the findings of Fang et al. (2011).Further, the beta coefficients for non-performing loans are positive and significant with bank efficiency which suggests that the non-performing loans have a positive impact on bank efficiency and it is consistent with the result of Onyango and Olando (2020). As the standard error of estimates measures the uncertainty associated with standard deviation of distribution, the last model of table 5 indicates least risky position which has the value of SEE is 12.444 and the first model shows the highest risky position with the value of SEE is 13.998 .

Table 6

Regression Results using Bank Profitability as the Criterion

\begin{tabular}{|c|c|c|c|c|c|c|c|c|}
\hline \multirow[t]{2}{*}{ Model } & \multirow[t]{2}{*}{ Constant } & \multicolumn{6}{|c|}{ Regression coefficients of } & \multirow{2}{*}{$\begin{array}{l}\text { Adj. } \\
\text { R_bar }\end{array}$} \\
\hline & & BS & CAR & Z-score & NPL & GDP & INF & \\
\hline \multirow[t]{2}{*}{1} & -1.687 & 0.431 & & & & & & 0.039 \\
\hline & -1.543 & $(2.981)^{* *}$ & & & & & & \\
\hline \multirow[t]{2}{*}{2} & 1.411 & & 0.132 & & & & & 0.009 \\
\hline & $(6.195)^{* *}$ & & -1.752 & & & & & \\
\hline \multirow[t]{2}{*}{3} & 0.997 & & & 0.127 & & & & 0.088 \\
\hline & $(5.305)^{* *}$ & & & $(4.489)^{* *}$ & & & & \\
\hline \multirow[t]{2}{*}{4} & 1.987 & & & & -0.19 & & & 0.099 \\
\hline & $(22.276)^{* *}$ & & & & $(4.923)^{* *}$ & & & \\
\hline \multirow[t]{2}{*}{5} & -2.778 & & & & & 0.435 & & 0.004 \\
\hline & -0.961 & & & & & -1.234 & & \\
\hline \multirow[t]{2}{*}{6} & 1.871 & & & & & & 0.089 & 0.003 \\
\hline & -7.971 & & & & & & -0.698 & \\
\hline \multirow[t]{2}{*}{7} & 1.431 & & & 0.096 & -0.176 & & & 0.241 \\
\hline & $(6.691)^{* *}$ & & & $(3.447)^{* *}$ & $(3.995)^{* *}$ & & & \\
\hline \multirow[t]{2}{*}{8} & 1.781 & & -0.132 & 0.127 & -0.187 & & & 0.252 \\
\hline & $(6.554)^{* *}$ & & -1.987 & $(3.998) * *$ & $(4.436)^{* *}$ & & & \\
\hline \multirow[t]{2}{*}{9} & 1.451 & & -0.113 & 0.167 & -0.189 & & 0.076 & 0.252 \\
\hline & $(3.817)^{* *}$ & & -1.998 & $(4.145)^{* *}$ & $(4.451)^{* *}$ & & -0.997 & \\
\hline \multirow[t]{2}{*}{10} & 9.871 & 0.651 & -0.007 & 0.079 & -0.198 & -1.186 & & 0.276 \\
\hline & $(2.821)^{* *}$ & $(3.671)^{* *}$ & -0.452 & $(3.841)^{* *}$ & $(4.451)^{* *}$ & $(3.124)^{* *}$ & & \\
\hline \multirow[t]{2}{*}{11} & 5.875 & 0.613 & -0.006 & 0.103 & -0.198 & -0.898 & 0.134 & 0.288 \\
\hline & -1.132 & $(3.673)^{* *}$ & -0.298 & $(3.844)^{* *}$ & $(4.452)^{* *}$ & -1.851 & -0.903 & \\
\hline
\end{tabular}


Notes:

i. $\quad$ Figures in parenthesis are t-values.

ii. The asterisk signs (**) and (*) indicate that the results are significant at one percent and five percent levels respectively.

iii. $\quad$ Profitability is the dependent variable

Table 6 states that positive and significant beta for banks size with profitability indicates that the bank size has a positive impact on bank profitability and this result is similar to the result of Parvin et al. (2018) and Khalil and Khalil (2017).Similarly, the positive beta coefficient for CAR with profitability reveals that the capital adequacy ratio has a positive impact on bank profitability and this finding is consistent with the findings of Datta and Mahamad (2019) and Agbeja et al. (2015). Likewise, the beta coefficients for Z-score are positive and significant with profitability which means that the Z-score has a positive impact on bank profitability and it is consistent with the result of Khaddafi et al. (2017) and Noman et al. (2017). Further, the negative and significant beta coefficient for non-performing loans with bank profitability indicates that the non-performing loans hurt bank profitability and this finding is consistent with the findings of Alshebmit et al. (2020) and Cetin (2019).Additionally, the beta coefficient for GDP is positive with profitability which indicates that the gross GDP has a positive impact on bank profitability and it is consistent with the findings of Yuksel et al. (2018) and Adekola (2016). The result also exhibits that the coefficient for inflation is positive with bank profitability that reports the inflation has a positive impact on bank profitability and this finding is similar to the finding of Raza et al. (2013). Similarly, the value of SEE of model 10 and 11 of table 6 is 0.908 that indicates the least uncertainty position and the value of model 6 is the highest (1.018) that shows the highest level of uncertainty.

Table 7 exhibits that the beta coefficient for bank size is positive with stability that states the bank size has a positive impact on bank stability and the result is similar to the findings of Odundo and Orwaru (2018). Similarly, the positive and significant beta coefficient for capital adequacy ratio with stability indicates the capital adequacy ratio has a positive impact on bank stability and it is consistent with the findings of Jahan (2020) and Olarewaju and Akande (2016). Further, it is observed that the beta coefficients for return on assets are positive and significant with stability and that indicates the return on assets has a positive impact on bank stability which is similar to the findings of Mbekomize and Mapharing (2017). However, the negative and significant beta for the cost to income ratio with bank stability reveals that the cost to income ratio hurts bank stability and the same result was found in the study of Muriithi and Muigai (2017) and Almumani (2013). It is also found that the beta coefficients for 
the gross domestic product are positive and significant with stability which proves the gross domestic product has a positive impact on bank stability. Further, a negative and significant beta coefficient for inflation with bank stability indicates that inflation hurts bank stability and this result is consistent with the findings of Kohler (2015). The value of SEE of $8^{\text {th }}$ model of table 7 is the lowest (4.999) and the value of the first model is the highest (6.241) that reveals the $8^{\text {th }}$ model and first model have lowest and highest level of uncertainty respectively.

Table 7

Regression Results using Bank Stability as the Criterion

\begin{tabular}{|c|c|c|c|c|c|c|c|c|}
\hline \multirow[t]{2}{*}{ Model } & \multirow[t]{2}{*}{ Constant } & \multicolumn{6}{|c|}{ Regression coefficients of } & \multirow{2}{*}{$\begin{array}{l}\text { Adj. } \\
\text { R_bar }\end{array}$} \\
\hline & & BS & CAR & ROA & CTI & GDP & INF & \\
\hline \multirow[t]{2}{*}{1} & 2.447 & 1.307 & & & & & & 0.032 \\
\hline & -0.385 & -1.92 & & & & & & \\
\hline \multirow[t]{2}{*}{2} & 5.383 & & 0.941 & & & & & 0.317 \\
\hline & $(4.704)^{* *}$ & & $(9.625)^{* *}$ & & & & & \\
\hline \multirow[t]{2}{*}{3} & 12.734 & & & 1.896 & & & & 0.099 \\
\hline & $(16.211)^{* *}$ & & & $(4.492)^{* *}$ & & & & \\
\hline \multirow[t]{2}{*}{4} & 19.871 & & & & -0.099 & & & 0.063 \\
\hline & $(14.935)^{* *}$ & & & & $(3.307)^{* *}$ & & & \\
\hline \multirow[t]{2}{*}{5} & -81.234 & & & & & 7.954 & & 0.125 \\
\hline & $(4.367)^{* *}$ & & & & & $(5.187)^{* *}$ & & \\
\hline \multirow[t]{2}{*}{6} & 21.561 & & & & & & -0.872 & 0.108 \\
\hline & $(16.142)^{* *}$ & & & & & & $(4.697)^{* *}$ & \\
\hline \multirow[t]{2}{*}{7} & 3.487 & & 0.875 & 1.545 & & & & 0.367 \\
\hline & $(2.927)^{* *}$ & & $(9.487)^{* *}$ & $(4.226)^{* *}$ & & & & \\
\hline \multirow[t]{2}{*}{8} & -57.875 & & 0.811 & 1.454 & & 5.111 & & 0.407 \\
\hline & $(3.698)^{* *}$ & & $(8.798)^{* *}$ & $(4.082)^{* *}$ & & $(3.935)^{* *}$ & & \\
\hline \multirow[t]{2}{*}{9} & -56.743 & & 0.761 & 1.375 & -0.097 & 5.126 & & 0.407 \\
\hline & $(3.616)^{* *}$ & & $(8.397)^{* *}$ & $(3.845)^{* *}$ & -0.977 & $(3.948)^{* *}$ & & \\
\hline \multirow[t]{2}{*}{10} & -52.235 & 0.403 & 0.795 & 1.335 & -0.092 & 4.447 & & 0.405 \\
\hline & $(2.865)^{* *}$ & -0.49 & $(7.699)^{* *}$ & $(3.589)^{* *}$ & -0.997 & $(2.243)^{*}$ & & \\
\hline \multirow[t]{2}{*}{11} & -39.467 & 0.448 & 0.775 & 1.365 & -0.123 & 3.516 & -0.197 & 0.402 \\
\hline & -1.387 & -0.49 & $(7.587) * *$ & $(3.619)^{* *}$ & -1.079 & -1.315 & -0.591 & \\
\hline
\end{tabular}

Notes:

i. $\quad$ Figures in parenthesis are t-values.

ii. The asterisk signs (**) and (*) indicate that the results are significant at one percent and five percent levels respectively.

iii. Stability is the dependent variable 
It is found that the first hypothesis (H1: There is a positive relationship of bank size with bank efficiency and profitability) is accepted. However, the second hypothesis $\left(\mathrm{H}_{2}\right.$ : There is a negative relationship of bank size with bank stability) is rejected. Similarly, the third hypothesis $\left(\mathrm{H}_{3}\right.$ : There is a negative relationship of capital adequacy ratios with bank efficiency) is accepted. Likewise, the fourth hypothesis $\left(\mathrm{H}_{4}\right.$ : There is a positive relationship of capital adequacy ratios with bank profitability and stability) is also accepted. However, the fifth hypothesis $\left(\mathrm{H}_{5}\right.$ : There is a negative relationship of nonperforming loan ratios with bank efficiency, profitability and stability) is accepted with efficiency and rejected with profitability and stability. Further, the sixth hypothesis $\left(\mathrm{H}_{6}\right.$ : There is a negative relationship of Z-score with bank efficiency, profitability and stability) is partially accepted. Moreover, the seventh hypothesis $\left(\mathrm{H}_{7}\right.$ : There is a positive relationship of cost to income ratios with bank efficiency) is accepted. Besides, the eighth hypothesis $\left(\mathrm{H}_{8}\right.$ : There is a negative relationship of cost to income ratio with bank profitability and stability) has been accepted with both efficiency, profitability and rejected with stability. Furthermore, the ninth hypothesis $\left(\mathrm{H}_{9}\right.$ : There is a positive relationship of return on assets with bank efficiency, profitability and stability) is partially accepted. In the same way, the tenth hypothesis $\left(\mathrm{H}_{10}\right.$ : There is a positive relationship of gross domestic product with bank efficiency, profitability and stability) has been partially accepted and finally, the last hypothesis $\left(\mathrm{H}_{11}\right.$ : There is a negative relationship of inflation with bank efficiency, profitability and stability) has been accepted.

\section{Conclusion}

It is observed that bank size and non-performing loans have a positive impact on bank efficiency. However, capital adequacy ratio and return on assets have a negative on bank efficiency. Likewise, bank size, Z-score, capital adequacy ratio, GDP, and inflation have positive impacts on the bank profitability but non-performing loans have a negative and significant impact on bank profitability. The stability measurement Z-score show that Nepalese commercial banks are in the process of stable in their overall performance. Capital adequacy ratio, return on assets, gross domestic product, and bank size has a positive impact on banks stability. However, the cost to income ratio and the inflation rate has a negative and significant impact on bank stability. It is found that banking efficiency is negatively and significantly related to profitability. However, a positive and significant relationship found between bank efficiency and stability; and between bank profitability and stability. It is also observed that capital adequacy ratio, returns on assets and non-performing loans are the most influencing factor that explains the changes in the bank efficiency. Similarly, bank size, Z-score and non-performing loans are the most influencing factor that explains the changes in the bank profitability. Further, capital 
adequacy ratio, returns on assets, cost to income ratio, gross domestic product and inflation rate are the most influencing factors that explain the changes in the stability of banks.

Based on the findings of this paper, it is suggested that cost to income ratio should decrease to increase the profitability and stability of banks; should increase return on assets ratio to increase stability; should increase efficiency, profitability, and stability to increase total assets; should increase return on assets and Z-score to increase capital adequacy, and should reduce the non-performing loan to increase profitability.

\section{Future scope}

Future research can be conducted by considering the Tobit model for efficiency, generalized least square (GLS), generalized methods of moments (GMM) and data envelopment analysis (DEA) that may increase the $\mathrm{R}^{2}$ indicators. Similarly, the researcher may research this topic on other financial institutions like development banks, finance companies, microfinance, cooperatives, and insurance companies. Further, other bank-specific variables like ownership structure, return on equity, financial leverage, loan growth rate, loan to total assets ratio, the board size, capital requirement, credit risk etc. may also incorporate in the research study.

\section{References}

Abd Karim, M. Z., Chan, S. G., \& Hassan, S. (2010). Bank efficiency and nonperforming loans: Evidence from Malaysia and Singapore. Prague Economic Papers, 2 (1), 118-132.

Abiodun, S. W., Abdul-Azeez, A. A., \& Adewale, Y. L. (2020). Determinants of capital adequacy of Nigerian banks. Market Forces, 15(1), 349-405.

Adekola, O. A. (2016). The effect of banks profitability on economic growth in Nigeria. Journal of Business and Management, 18(3), 1-9.

Agbeja, O., Adelakun, O, J., \&Olufemi, F. I. (2015). Capital adequacy ratio and bank profitability in Nigeria: A linear approach. International Journal of Novel Research in Marketing Management and Economics, 2(3), 91-99.

Akhter, N. (2018). Assessing the relationship between efficiency, capital and risk of commercial banks in Bangladesh. International Journal of Business and Management, 14(1), 1833-8119.

Alber, N. (2017). Banking efficiency and financial stability: Which causes which? A panel analysis. Advances in Applied Economic Research, 7(9), 91-98.

Alharthi, M. (2016). The Determinants of Efficiency, Profitability, and Stability in the Banking Sector: A Comparative Study of Islamic, Conventional and Socially 
Responsible banks. Degree of Doctor in Philosophy submitted to Economic and Finance Plymouth Business School. England, U. K.

Ali, M., \&Puah, C. H. (2019). The internal determinants of bank profitability and stability. Management Research Review, 1(42), 49-67.

Almumani, M. A. (2013). Impact of managerial factors on commercial bank profitability: Empirical evidence from Jordan. International Journal of Academic Research in Accounting, Finance and Management Sciences, 3(2), 298-310.

Alshebmi, A. S., Adam, M. H.M., Mustafa, A. M., \&Abdelmaksoud, M. (2020). Assessing the non-performing loans and their effect on banks profitability: Empirical evidence from the Saudi Arabi banking sector. International Journal of Innovation, Creativity and Change, 8(11), 1201-1323.

Andrieş, A. M., \&Capraru, B. (2014). The nexus between competition and efficiency: The European banking industries experience. International Business Review, 23(3), 566-579.

Apergis, N. (2014). The long-term role of non-traditional banking in profitability and risk profiles: Evidence from a panel of US banking institutions. Journal of International Money and Finance, 2(45), 61-73.

Athanasoglou, P. P., Brissimis, S. N., \& Delis, M. D. (2008). Bank-specific, industryspecific and macroeconomic determinants of bank profitability. Journal of International Financial Markets, Institutions and Money, 18 (2), 121-136.

Belas, J., Kocisova, K., \&Gavuroca, B. (2019). Determinants of cost-efficiency: Evidence from banking sectors in EU countries. ActaPolytechnicaHungarica, 16(5), 101-123.

Bergre, A. N., Hunter, W. C., \& Timme, S. G. (1993). The efficiency of financial institutions: A review and preview of research past, present and future. Journal of Banking \& Finance, 17(2-3), 221-249.

Cetin, H. (2019). The relationship between non-performing loans and selected EU member's banks profitability. International Journal of Trade, Economics and Finance, 10(2), 622-637.

Cvilikas, A., \& Jurkonyte-Dumbliauskiene, E. (2016). Assessment of risk management economic efficiency applying economic logistic theory. Transformations in Business \& Economics, 15(3/39), 207-219.

Datta, C. K., \& Al Mahmud, M. (2019). An impact of capital adequacy on profitability under Basel II accord: Evidence from commercial banks of Bangladesh. European Journal of Business and Management 8(10), 2222-2839.

Fang, Y., Hassan, I., \& Marton, K. (2011). Banking efficiency in South-East Europe. Transition, 19(2), 495-520. 
Gajurel, D. (2010). Cost efficiency of Nepalese commercial banks. Nepalese Management Review, 1(1), 12-13.

Hafez, H. M. M. (2018). Examining the relationship between efficiency and capital adequacy ratio: Islamic versus conventional banks. Accounting and Finance Research, 7(2), 232-47.

Jahan, N. (2020). Influence of capital adequacy on the growth of the banking sector in Bangladesh. Ictact Journal on Management Studies, 4(5), 2395-1664.

Kenourgios, D., \& Samitas, A. (2007). Financial development and economic growth in a transition economy: Evidence for Poland. Journal of Financial Decision Making, 3(1), 35-48.

Khaddafi, M., Falahuddin, F., Heikal, M., \& Nandari, A. (2017). Analysis Z-score to predict bankruptcy in banks listed in the Indonesia stock exchange. International Journal of Economics and Financial Issues, 7(3), 326.

Khalil, R., \& Khalil, M. A. (2017). Do bank size and operational efficiency matter? An impact of financial gearing and asset management on Islamic bank's performance in Pakistan. Journal of Accounting and Finance emerging Economies, 3(1), 63-78.

Khan, M. A., Siddique, A., \& Sarwar, Z. (2020). Determinants of non-performing loans in the banking sector in developing states. Asian Journal of Accounting Research, 5(1), 135-145.

Kohler, M. (2015). Which banks are more risky? The impact of business models in bank stability. Journal of Financial Stability, 1(16), 195-212.

Lardic, S., \& Terraza, V. (2019). Financial ratios analysis in determination of bank performance in the German banking sector. International Journal of Economics and Financial Issues, 9(13), 22-47.

Lotto, J. (2019). Evaluation of factor influencing bank operation efficiency in the Tanzanian banking sector. Cogent Economics \& Finance, 7(1), 2332-2039.

Mathuva, D. M. (2009). Capital adequacy, cost-income ratio and the performance of commercial banks: The Kenyan Scenario. The International Journal of Applied Economics and Finance, 3(2), 35-47.

Mbekomize, C. J., \& Mapharing, M. (2017). Analysis of determinants of profitability of commercial banks in Botswana. International Journal of Academic Research in Accounting, Finance and Management Sciences, 7(2), 131-144.

Miah, M. D., Uddin, H., \& Ahmed, N. N. (2020). Determinant of efficiency and stability: Evidence from private commercial banks in Bangladesh. International Journal of Accounting and Finance, 9(2-4). 152-169. 
Murerwa, C. B. (2015). Determinants of banks; financial performance in developing economies: evidence from Kenyan commercial banks (Doctoral dissertation, United States International University-Africa).

Muriithi, L., \& Muigai, R. (2017). Quantitative analysis of operational risk and profitability of Kenyan commercial banks using cost-income ratio. IOSR Journal of Economics and Finance, 8(3), 76-83.

Noman, A. H. M., Gee, C. S., \& Isa, C. R. (2017). Does competition improve the financial stability of the banking sector in ASEAN countries? An empirical analysis. PloS one, 12(5). e0176546.

Odundo, O. G., \& Orwaru, M. J. (2018). Bank size and financial stability of commercial banks in Kenya: empirical evidence, Journal of Emerging Issues in Economics, Finance and Banking, 7(1), 2667-2680.

Olarewaju, O. M., \& Akamde, J. O. (2016). An empirical analysis of capital adequacy determinants in the Nigerian banking sector. International Journal of Economics and Finance, 8(12), 1916-9728.

Onyango, W. A., \& Olando, C. O. (2020). Analysis on influence of bank-specific factors on non-performing loans among commercial banks in Kenya. Advances in Economics and Business, 8(3), 105-121.

Ozili, P. K. (2019). Determinants of banking stability in Nigeria. CBN Bullion, 43(2), 339-2963.

Panta, S. B., \& Bedari. D. P. (2019). Cost efficiency of Nepali commercial banks in the context of regulatory changes, NRB Economic Review, 27(2), 58-69.

Pradhan, R. S., \& Gajurel, D. P. (2011). Structure Performance Relation in Nepalese Banking Industry. International Conference on Economics, Business, 2.

Rahman, M. M., Hamid, M. K., \& Khan, M. A. M. (2015). Determinants of bank profitability: Empirical evidence from Bangladesh. International Journal of Business and Management, 10(8), 135-146

Raza, S. A., Jawaid, S. T., \& Shafqat, J. (2013). Profitability of the banking sector of Pakistan: Panel evidence from bank-specific, industry-specific and macroeconomic determinants.

Rivai, V., Veithzal, A. P., \& Idroes, F. N. (2007). Bank and Financial Institution Management Conventional and Sharia System. Jakarta: Raja Grafindo Persada.

Safavi, F. (2014). Causes of economic stagnations from the views of Iranian bankers: is the global sanction a major factor. International Journal of Business \& Economics Perspectives, 9(1), 81-96.

Shijaku, G. (2016). Banking stability and its determinants: A sensitivity analysis on methodological changes. The Economic Review, 1(1), 18-30. 
Stancic, P., Cupic, M., \& Obradovic, V. (2014). Influence of board and ownership structure on bank profitability evidence from South-East Europe. Economic research-Ekonomskaistrazivanja, 27(1), 573-589.

Sufian, F. (2016). Determinants of efficiency in the Malaysian banking sector: Evidence from semi-parametric data envelopment analysis method. Studies in Microeconomics, 4(2). 151-172.

Sulaeman, H. S. F., Moelyono, S. B., \& Nawir, J. (2019). Determinants of banking efficiency for commercial banks in Indonesia. Contemporary Economics, 13(2), 205-218.

Tan, A. Y., \& Anchor, J. R. (2016). Stability and profitability in the Chinese banking industry: Evidence from an auto-regressive-distributed linear specification. Investment Management and Financial Innovations, 13(4), 120-128.

Thagunna, K. S., \& Poudel, S. (2013). Measuring bank performance of Nepali banks: A data envelopment analysis (DEA) perspective. International Journal of Economics and Financial Issues, 3(1), 54-67.

Thalassinos, E., Pintea, M., \& Ratui. P. I. (2015). The recent financial crisis and its impact on the performance indicators of selected countries during the crisis period: A reply. International Journal of Economics \& Business Administration, 3(1), 3-20.

Vinh, N. T. H. (2017). The impact of non-performing loans on bank profitability and lending behavior: Evidence from Vietnam. Journal of Economic Development, 24(3), 27-44.

Vu, H., \& Nahm, D. (2013). The determinants of profit efficiency of banks in Vietnam. Journal of the Asia Pacific Economy, 18(4), 615-631.

Yildirim, C. (2010). Evolution of banking efficiency within an unstable macroeconomic environment: the case of Turkish commercial banks. Applied Economics, 34(18), 2289-2301.

Yuksel, S., Mukhtarov, S., Mammadov, E., \& Ozsari, M. (2018). Determinants of profitability in the banking sector: An analysis of post-soviet countries. Economies, 6(3), 41.

Zhang, j., Wan, P., \& Qu, B. (2012). Bank risk-taking, efficiency, and law enforcement: Evidence from Chinese city commercial banks. China Economic Review, 23(2). 284-295.

Zheng, C., Moudud-Ul-Huq, S., Rahman, M. M., \& Ashraf, B. N. (2017). Does the ownership structure matter for banks' capital regulation and risk taking behavior? Empirical evidence from a developing country. Research in International Business and Finance, 1(42), 404-421. 